\title{
The China-Africa Relations: Between the Development Cooperation and Economic Diplomacy
}

\author{
Maiga Aly \\ Department of International Relation, School of Politics and International Studies, China Central Normal University (CCNU), \\ Wuhan, China \\ Email: alymaiga82@yahoo.fr
}

How to cite this paper: Aly, M. (2019). The China-Africa Relations: Between the Development Cooperation and Economic Diplomacy. Open Journal of Political Science, 9, 291-298.

https://doi.org/10.4236/ojps.2019.92016

Received: January 30, 2019

Accepted: February 23, 2019

Published: February 26, 2019

Copyright $\odot 2019$ by author(s) and Scientific Research Publishing Inc. This work is licensed under the Creative Commons Attribution International License (CC BY 4.0).

http://creativecommons.org/licenses/by/4.0/

\begin{abstract}
A spectacular ascent having made it possible to move from a continental economy to external influences to one of the greatest trading powers of the world, China has, in a few years debunked all the dogmas that wanted an economy initially low can very easily gain access to economic supremacy. The reform of its economy, begun in 1978 under the impetus of the Government of Deng Xiaoping and later its accession to the World Trade Organization, allowed the gradual opening of the country to the international markets and generated phenomenal growth which occurred thereafter. However, relations between China and Africa date back to the years 1960. Very early on, China developed diplomatic contacts with these African countries. China has in fact supported the newly independent African countries and has actively participated in consolidating local liberation movements in logic of anti-colonization. In Africa, since the period of socialist regimes, China has Darcy its aid in the construction of industrial fabric in some African countries and the development of production plants. These contacts between China and the African countries have succeeded, over the course of the political regimes, in developing a partnership and a particularly strong bilateral relationship. China continues to carry out major construction projects in Africa. China provides non-cost-specific loans to African countries and in return, it receives raw materials for its needs. It floods African markets with products with dubious quality and at the same time responds to African emergencies. It is therefore indispensable for the African countries affected by Chinese character and China to analyse the consequences, both positive and negative for the growth and development of their respective countries.
\end{abstract}

\section{Keywords}

Economy, Diplomacy, Development 


\section{Introduction}

China, with the emergence and the spectacular development of his economy, that confer him the place of second world economic power, develops today a south-south cooperation with Africa, who overflows a lot with raw materials. China is anxious to obtain the quantities of raw materials with least cost. She turned to the African continent which is a real bargain for China. In exchange for certain services, China is committed to meeting the financing needs of countries in difficulty and to addressing urgent needs in infrastructure (roads, airports, ministries), for many of these African nations.

Since the Bandung conference in 1955, marked by the birth of the Non-Aligned Movement, China underlines its commitment to Africa against imperialism, colonialism and all forms of Western hegemony. Except the large range of domain to the breast of which China intervenes in Africa, the Chinese strategy can also be susceptible to reveal some diplomatic aspects being connected the very creation of the popular Republic. In spite of the anguishes of its own economic history, China puts no negligible actions towards Africa, as the financing of a food help project for the Guinea in the years 1960, or the engagement of its workers in the construction of the Tazara railroad (Tanzania-Zambia). These initiatives mark China's willingness to prove its reputation and although this initiative remains to be relativized because of the fact that Chinese cooperation has its influence in Africa. Henceforth, the economic realities instituted by the western powers in the setting of Africa are the subject of a big discount in question. With the launching in October 2000 of the FOCCA: the forum of cooperation China-Africa, whose last edition was held at Beijing of November 20063 to 5, a flat shape of cooperation got in place and permitted China to reaffirm his engagement towards Africa. This regrouping destined to help the countries members to compose with the challenges of the 21 st century, and dragged the adoption of struggle measures notably against poverty. It marked the funding of the economic and political ties existing between the two regions. In beginning 2006 jointly to the holding of the 3rd ministerial meeting, Beijing conducted the publication of a structural document on the modes of his official politics in Africa.

Even though this initiative stays to be relativized because of the fact that the China-Africa cooperation presents also a lot of advantages and the inconveniences, it marks an important significance in the intensity of the China-Africa relations. Otherwise according to statistics of the UNO, the trade between China and Africa had nearly tripled between 2000 and 2005, passing from 12 billion of US dollars to 40 billion of dollars. To the light of these numbers that speak, it appears clear that China is at the origin of the growth of several African states, the major part of this collaboration takes place in the oil, mining and industrial domains.

Regardless of these elements, the inter-state cooperation to the level of the education is also in full expansion. According to the numbers, in September 2008, China had granted over 21,000 scholarships and for more than 50 African 
countries. The China-Africa relations possess a strong character, therefore, at a time being multi-dimensional and multiform. China now stands as a power claiming the position of the first trading partner of African countries.

This problem brings us to the heart of cooperation and the commercial tendencies between China and the African countries since these last years. The Chinese presence in Africa is particularly emblematic. Contrary to Europe and to the United States, China doesn't condition its aide and its investments to the political criteria respect. The questions that arise are the following:

Is Cooperation Sino Africa really beneficial for the development of Africa?

What factors are motivating the Sino-African cooperation to establish some ties diplomatic with a big power?

What conclusion can we get from the future of the relation of China-Africa?

Based on these questions, our research subject is in four parts: Chinese economic power in the first part, Chinese politics in Africa in the second part. The third part presents the impact of Chinese diplomacy on African countries. The development of Sino-African relations is in the fourth part. And the fifth part presents the conclusion.

\subsection{Definition of Concepts}

\subsubsection{Economy}

Economy is the science that studies how scarce resources are used for the satisfaction of the goods of men living in society this normative science, the economy must therefore analyze the best way to organize the production, distribution and The consumption. It must provide us with the conceptual means for judging the comparative advantages of various forms of organizations.

\subsubsection{Development}

The term development used in the social sciences, refers to the improvement of the conditions and the quality of life of a population, and refers to the social organization as a framework for the production of well-being. Development is therefore qualitative and quantitative. The Indian economist Amartya Sen, to explain has developed a human development indicator (JHR), (see article "Development Evaluation").

\subsubsection{Diplomacy}

Diplomacy is the conduct of negotiation and diplomatic recognition between groups of people or nations by settling cases without violence. Thus in the history of international relations, Pierre Renouvin, highlights that "the study of international relations focuses on analyzing and explaining the relations between the political communities organized within the framework of a territory", That is, the states.

\section{The Chinese Economic Power}

China in the years 1970 was trying to modernize its economy which was much more internal. However the coastline was already in contact with the outside 
world. It is necessary to wait until the years 1980 , to start a real economic modernization open to the world. With the mobilization of internal resources and a considerable investment effort to modernize the industry and develop infrastructure, China has also attracted a lot of foreign investors who have played a decisive role and created new industrial production capacities in the sectors that carry domestic and international demand. So China has taken advantage of globalization. China has become a big power first by the weight of its demographic population that has greatly improved the standard of living of the Chinese. In this respect, the evolution of the Chinese economy, the economic and social transformations still continue at the rate of foreign investment in the country.

The political configuration to meet the vastness of its territory, leads it to take well-structured policies from the coast to the centre of the country to the west of the country. China now appears as a unitary state to the size of Europe and the average area of its provinces is equivalent to that of Great Britain. President Deng Xiaoping's major policy lies in the choice of economic development, a factor of development, an internal enrichment factor, but also a power vector in today's world. The formidable growth relaunched after the years 1992, has deeply upset China's economic and social structures. Towns have been transformed into mega-cities and the urban world is far more important than the countryside. The rural world is bursting according to its distance to the city and its ability to integrate into the economic, regional, national and international networks.

The Chinese economic power, not to mention its political, diplomatic and cultural influence, is projected on all continents. China finds its customers in Asia, Africa, and Latin America, both in the United States and in Europe. With which it records significant trade surpluses. It is today the heart of world trade, which makes all its economic power global.

\section{Bilateral Development China-Africa}

The logic of weak cost also applies to the trade between China and Africa (Capstan, 2015; Lemoine, 2007). Indeed, thanks to relatively weak costs of operation and hand of work, China imposes itself henceforth like a partner of choice for the African countries. At the end to seize the size of the phenomenon, one can mention the fact that close to 130,000 Chinese, are installed mainly in Africa to Zimbabwe, Nigeria, Angola and in Guinea. This famous fact well the new politics of outside trade with Africa thrown by the Chinese government. So following a certain lull of the years 1980 and the middle of the years 1990, the African Chinese exchanges took their vitalities. In return for some consumer goods currents, Africa provides the raw materials and the hydrocarbons of which miss China. The logic is therefore as very economic as geopolitics. China defends the energizing resources of which she has need ardently but affirms to want to become unified also with Africa since the years 1950 to fight the "imperialists". She 
will provide its military support besides in several African nations that will shoulder it on their turn in the setting of its different with Taiwan. In the beginning of the years 1980, China maintains diplomatic relations with meadows of 40 African countries and expense meadows of 100 millions of dollars per year in help to the development. Is displeased the exchanges with the African are multiplied by 50 between 1980 and 2010. For import, the main goods coming from West Africa are oil and cotton (this last supplies the Chinese industry). China became besides first commercial partner of the big country producers of cotton as Burkina, Mali, Chad and again Benin. In spite of the upsurge of the exchanges and relations woven, it is important to signal that the part of the transactions with Africa stays marginal to the scale of the Chinese trade (Shambaugh, 2013; Lacoste, 2007). They constitute in fact 2.5 percent of the outside trade of China. Africa doesn't represent a major stake truly for the good to be economic of China, even though the consequences at a time positive and negative of this cooperation remain very present for the continent and his inhabitants.

\section{The Impact of China's Diplomacy on the African Countries}

The African reports knew a very clean upsurge these last years, whereas China under the impulse of a new government, decided to lead a politics of reforms and of opening with the international exchanges. However, even though it is these last 10 years that the international attention turns toward this phenomenon the two groups share a common economic past. Indeed with sound articulates title "it is Necessary to be afraid of China?" Appeared in the magazine young Africa (November 2006). Mr Roger Sokorobi Afris presides the AHIDA UNG and the LICA project in Cote of Ivory and teaches us that the historic ties "deep and strong unite China and good number of African countries". According to this author, these centennial relations make integral part of the reasons of the fast evolution as well as the present intensity of the Sino-African relations.

In fact contacts between China and Africa go back up to already more than 3000 years. The vestiges archaeological and former Chinese ceramics recovered in different regions of Africa, active of Timbuktu (to the north of the present Mali) to the big channel of Mozambique situated in the south of the continent, illustrating the type of exchanges that the two civilizations maintained then. According to Mr Afri the indirect contacts between China and Africa would have begun under the Han dynasty, with the evolution of the available technologies these contacts would have entered certainly at the time, in a phase of direct exchanges and new regards would be enjoyed woven late, in the beginning of the 15 th century when China came closer king of the "country of the shrewd" (present Kenya). All time it is around the years 1950 that the Sino-African cooperation takes its present shape, has when many African countries face the challenges of the colonization and the independence newly acquired. Of years 1950 to the years 1980, China attends the African countries in the independence movements, sustains more than 800 projects in Africa, including help to the realization of initiatives in agriculture, the fishing, textiles, the energy, the infrastruc- 
tures, the conservation of water etc. This precocious support of China has then the effect of reinforcing and to reaffirm the relations woven with the young African governments. The partners unite in logic of "solidarity of third monadiste". China increases its aide to the African governments and applying its politics of "mutual respect" and "worry continually for the diversity".

In counterpart, China bound alliances of choice with the African countries and gotten of the unconditional supports in the recognition of its sovereignty opposite Taiwan.

As Mr Ndubisi Obiora explains it to us in his article title "who's has fraid of China-Africa? Towards year African civil perspective society one China-African Relations" (2007), the Sino-African cooperation continued extensively to the 21 st century. Since 2000 the China-Africa forum was at the origin of the launching of a mixed economic and social program. Besides, China took advantage of the opportunity to annul the debt of 10 millions of US dollars that overwhelmed several African states. In December 2003, at the time of the holding of the 2nd edition of the forum, it conducted in the same momentum the relief of the debt of 31 African countries. For these initiatives and help that it has provided, China has many time reaffirmed its will establish strong political and commercial relations with Africa.

This politics of closeness with Africa is on line direct with its own need of natural resource, stability and economic development, at the same time the way to make Chinese present a considerable appeal in the African countries until they're accustomed to the hand bet western. As Mr Afri specifies it in article, Pekin leads before all "one political flexible and bearer of hope greatly appreciated by the African". Indeed, the Chinese government respects the sovereignty of the African countries in terms of politics and of economic and convenient therefore a politics of non interference in state affairs of the countries with which, it maintains some exchanges. Since, one of the aspects important of the Chinese politics is "to institute the peace and to bring the true development". Strong of its experience to the level of the techniques of productions, a lot of African hope that China will be able to help Africa to exploit his economic potential and so to generate wealth to the populations with only 200 millions of hectares of cultivated earths, 900 millions of earths available to the raising to all time and 40pour hundred of the reserves of water of the planet, Africa stays a continent to the unused reserves, of which the agricultural development remained to make again. To participate in this development, China should collaborate therefore with the local nongovernmental organizations and put some organizations in place within the civil society in order to surround the African needs better and to materialize the measures taken at the time of the different forum China-Africa.

However in spite of the good intentions that China seems to have with regard to these partners of the African continent, a lot of critiques rise as well on behalf of the western experts that of the African them even. Indeed numerous are those that affirm the upsurge of the exchanges with Africa and the presence of Pekin in many African regions translate the will of China to assure the pursuit of his 
national interests. In its work Africa title "in china's global strategy" (2007), the Dr Marcel Kitissou, historian and political expert explains besides that China constantly tried to form the alliances and the lasting international structures in order to protect its interests in the setting of the "global system".

China is conscious that even though the present era of internationalization ends, the international relations built very early with reliable partners will survive the mutations of the world economy. Because of all these constraints, many experts are of opinion to say that while trying to serve Africa and to stop its problems, China looks for above all to solve the challenges that puts him the size of its own population and its territory.

\section{The China and African Countries}

Since these last 30 years, the acceleration of the internationalization phenomenon as well as the reduction of the physical gates to the trade incited many countries to work in favor of a liberalization of their economy. Several nations that accused at the screen uncertain economic delay have the possibility to start an inherent beneficial reorientation to their outside trade politics. They could initiate a real economic renewal and could integrate more forward to the economic and political dynamics prevail on a world scale (Pina-Guerassimoff, 2012). Him's acts of the example of the INC (Industrialized New Countries) of Asia as the "4 dragons" is South Korea, Taiwan, Singapore, or Hong Kong that have forcing to reform their savings in the goal to promote a sustained growth.

As 3rd world exporter, China stood in real pionnière of this opening logic at the end of the years 1970 and occupies today, thanks to efforts marked on the international stage, leader's position in the world exchanges, goods and services. In initiatives of expansion of markets, China is created certain dependence towards the outside strengths and encouraged the south-south exchanges therefore. China achieved the partnerships and non negligible investments for example in Africa, exploiting a vein that had been abandoned little by the colonial powers as France and the United States. Indeed the economic situation at the very least precarious of the African continent, in fact an ideal candidate to the projects of cooperation and helps to the development. In West Africa, China frequently collaborates with the governments for the major infrastructure construction (tarred roads, official buildings, etc.). These Sino-African understanding allow the African states therefore to palliate to the lacks of enterprises of their hands of work and this to least cost. In exchange, Pékin interview important needs in raw materials while drawing in the African reserves. Several countries as Congo, South Africa or Nigeria procures him of this fact the hydro carbides and the agricultural commodities (cotton) necessary to the food of own production. In spite of the economic activity that it created for the implied nations, many are of opinion that this phenomenon is also susceptible to harm considerably to the local industries whose hand stays late of many these China-Africa projects. However that may be, the reality is that since several years already, the relations between the Chinese government and those of the African 
countries remain to the good stationary. Besides following the previously mentioned China-Africa Forum, the leaders of the two regions reaffirmed their engagement and establish some objectives crucial to reach for the China-Africa collaboration. Indeed, at the end of this meeting, that gathered a lot of economic actors (entrepreneurs, economic persons responsible etc.), China had invested more 100 billions of US dollars with Africa in 2010. Besides to the amount of contracts signed with the various African partners rises to 19 billion million. Because of this new commercial deal, Europe and the United States must review their diplomatic approaches henceforth as for the political and economic realities that they maintain with the African continent.

\section{Conclusion}

The cooperation China-Africa is very complex since these last 10 years in the political and economic surrounding, he stays very difficult to pull definitive findings on a dynamics in constant change. The geopolitics interest that unites dyes it and Africa is the very powerful incentive that constantly nourishes the interactions between the two blocks. The necessity to reach the political stability and some important catalysts mean to feed its enormous needs in natural resource to the actions of Chinese help in Africa. It is not necessary to omit the fact that contrary to the western powers, China allied very early to the African countries to fight imperialisms and to sustain the movements of liberation through the continent. So the past and present initiatives of Pekin as the preferential loan concession and the annulment of the debts resound as proofs of the Chinese determination to pull Africa from its economic and social gulf and to answer the emergency of the needs of the least advanced countries.

\section{Conflicts of Interest}

The author declares no conflicts of interest regarding the publication of this paper.

\section{References}

Capstan, J.-P. (2015). The International Politics of China. Between Integration and Will of Power (2nd ed. update and enriched). Paris: Presses of Sciences-Po.

Lacoste, Y. (2007). China Change the "Order" of the World, Hérodote in, No. 125, Second Semester, p. 4.

Lemoine, F. (2007). The Rise in Power of China and the Economic Integration Asia in, Hérodote in, No. 125, Second Quarter, p. 62.

Pina-Guerassimoff, C. (2012). China and Its New Diaspora. The Mobility to the Service of the Power. Paris: Ellipses.

Shambaugh, D. (2013). China Goes Global. The Biased Power, New York, Oxford University Press. 